\title{
Repositioning Culture in International Relations: Confucianism as Geopolitical Instrument
}

\author{
Ariffah Isna Amalia \\ Universitas Brawijaya
}

\begin{abstract}
Confucianism is a culture taken from the name of a thinker, namely Confucius, and is considered the basis of Confucian teachings. The primary view of Confucianism is to invite people to live an orderly, peaceful, and happy life replacing the rulers as one of the key factors in achieving country ideals. This study aims to identify and evaluate the chronology of Confucianism and its implications for China's geopolitical sustainability. The method used is qualitative with constructivist ideas to create a comprehensive thought allocation on the impact of Confucianism from the perspective of cultural superiority. The results obtained are that, over time, Confucianism has developed into a tool for the Chinese state to carry out geopolitical instruments to achieve geostrategy for expanding territorial boundaries. On the one hand, Confucianism can become a superior culture that places the people's fighting spirit. On the other hand, this flow can become a trigger for war when each region to be recruited for China's expansion has a culture and beliefs different from their own.
\end{abstract}

Keywords: Confucianism, China, Geopolitics, Geostrategy.

\section{INTRODUCTIONS}

Each country has different interests in directing progress, cultural schemes, and social order that the state must own. China is one of the countries in the Asian region that uses its cultural instruments to form geopolitical aspects. It serves as a network to obtain existing geostrategy to date, including from the country's limitations.

According to Lasiyo (2018) research, in China, Confucianism was born during the decline of Chou's rule (771-221 BC), motivated by the nomadic war that invaded Chou kingdom territory and carried out robberies. Nomad's existence threatens the success of Chou's kingdom. The impact of this war was that the Nomads managed to cripple the capital's defenses. Thus, the redevelopment of the Chou kingdom refers to the reign of prince Chou due to his displacement, giving meaning to the Eastern Chou period (new Chou period, because the capital is to the east of Hao as the old Capital). The trend of the Eastern Chou period is the gap between the central ruler, the kingdom, and the feudal ruler. The feudal rulers themselves were the autonomy of the central government in power in the regions. While the power of feudal rulers is considered more than the power of the kingdom itself, because of the expansion of the territory that is the feudal ruler. So, in the end, there was a war for power. This war becomes a stimulus in creating geostrategic boundaries of the desired country (Lasiyo, 2018).

To review the phenomenon of Confucianism, the perspective related to the issue is the primacy of superiority of a culture that can control society to a national and international scale. According to Brzezinski's theory (1997), Cultural Superiority is a cultural advantage 
tangible from the assumption or belief that the country has superior and more dominant culture and is widely done or used as an ideology of life for other countries (Brzezinski, 1997). So it can be assumed that the existence of Cultural Superiority over Confucianism influences the Chinese state to position itself in the international system.

Thus, based on the review of the phenomenon, it is fascinating to review this issue in this paper further entitled: "Phenomenon Of Confucianism As A Geopolitical Instrument From A Cultural Superiority Perspective". The purpose of this writing is to evaluate how Confucianism can occur in China and how it is implemented as an instrument in geopolitics that can produce geostrategy. The phenomenon is reviewed from a perspective on the cultural superiority of Chinese society.

\section{RESEARCH METHOD}

The research design in the article journal is to use qualitative research methods that study cases and contexts to understand the meaning of social action on Confucian phenomena. The qualitative approach was chosen because it can interpret data by giving meaning, translating, and arranging it to be easy to understand. While qualitative researchers are interpreting data on the influence of Confucianism on geostrategy and geopolitics in China, the data used is secondary data, including literature journals and books. The scope of this research method is based on the constructivist paradigm. In discovering a reality of Cultural Superiority in Confucianism.

\section{A. Cultural Superiority}

In accordance with the terms adopted by the World Commission on Culture and Development, culture is broadly defined, including various aspects of the way of life that society provides for ethics, pluralism, human rights, gender roles, the status of minority groups, religion, and language issues. Global culture cannot replace the feelings, identities, and directions from national and local or regional cultures, as only this provides continuity from community to community (SIDA. 1997).

While according to the theory by Greg (2020), Cultural Superiority is a term that is interpreted as the belief that one's culture is superior to other cultures in its implementation, influenced by many factors. The main factors that influence it are the development of civilization owned by one country that can be reviewed from high life expectancy and the advancement of economic levels and modern lifestyles (Clydesdale, 2020).

In addition to these factors, several other factors influence the existence of Cultural Superiority, namely social security and the provision of law and justice in the laws of a country, because the people in the country have pride in their country that can accommodate the needs of livelihoods. Other factors, namely accountability and strong efforts to eradicate corruption, harm the country and hinder development. People in developed countries consider that the nation's culture is the best, but it is not necessarily acceptable to everyone.

\section{B. Geostrategic and Geopolitical Theory Concept}


According to Krista (2019), it is confirmed that the study of geostrategy and geopolitics is a study that has the conception to assess the position of a country (Surbakti, 2019). Based on Nina's theory (2020), explains that geostrategy includes the cumulative role of history, which refers to the typographical power of the country's territory concept in a strategic position. In addition to the existence of strategic territorial areas, geostrategy is not spared from the geopolitical capabilities of the country can maintain its position (Lebedeva, 2020). In contrast, one of the conceptions of the geopolitical power of the country is the culture attached to the country, which forms the sociological system of society and also becomes the characteristic of a government in making decisions (Kristensen, 2019), where the cultural instrument based on this paper is Confucianism.

\section{RESULT AND ANALYSIS}

\section{A. The Phenomenon of Confucianism in China as a Geopolitical Instrument}

On geopolitical instruments to achieve a geostrategic outcome, the Chinese state is more focused on developing a Confucian-focused human philosophy. According to previous research by Purwanta (2004), Confucianism is a tradition that refers to the view of life in the ruling environment (royal and imperial palaces) that successfully developed into one of the icons of Chinese civilization. One of the philosophical traditions whose influence in Chinese history was Confucianism. This tradition was able to penetrate into the powerful environment (royal and imperial palaces) and managed to develop into one of the icons of Chinese civilization. Confucianism grew into a symbol of the highest best character of Chinese society. A ruler would be considered good if he became a loyal follower of Confucianism and was able to apply his various teachings. Even in the before century, Confucian teachings were used as a means of selection in the acceptance of court employees. A person will be accepted as a civil servant if he passes the test with Confucian teachings (Purwanta, 2004).

Confucianism was born and began to flourish when the rule of the Chou dynasty suffered a setback culminating in a long civil war (771 - 221 BC). Two periods of war during the reign of the Chou Timur dynasty brought unexpected complex influences in the Chinese people's living order. Culturally, the war resulted in expanding the reach of Chinese (Chou) cultural influence. Various barbaric tribes, such as Yueh and Tai in southern China, were initially beyond Chou dynasty influence. Through their involvement in the war, various tribes began to get acquainted and absorb elements of Chou culture. The expansion of cultural influence is a fairly important phase in forming cultural parallels. In the next stage, it supports the development of geopolitical unity in the next period (National Geographic, 2018).

Confucianism is the name of a school taken from a thinker, Confucius. It is considered the basis of Confucian teachings. There are quite a lot of students and come from various circles. Among his followers are two famous figures, namely Hzun Tzu and Meng Tzu (Mencius). The primary view of Confucianism is that an orderly, peaceful, and happy life is everyone's dream. In that framework, rulers are key factors in achieving these ideals. If the ruler has the wrong character, inevitably, the people will experience pressure and suffering. If the ruler is kind, respectful, and even prioritizes the people's interests, the people will live with prosperity and peace, which is an important part of realizing universal harmony. 
Confucianism grew into a symbol of the highest character of all Chinese society. Confucianism is also very close to bureaucracy because it has the principle of one's power regardless of an agreement. Confucianism also plays a role in improving the order and regularity of a rule based on the importance of the role of a leader so that if the leader has a good attitude, then the country led will prosper. Society will be more prosperous, while if the leader has a bad temper, then the prosperity of his people will also be threatened (Weiming, 2019).

The period of the Confucian era was driven by the Autumn Spring (MSMG) period, which was done simply by strengthening entrepreneurship during the war. Mobility in combat is using horses and iron weaponry technology. The impact of this war was that two periods of war resulted in cultural destruction because various tribes invaded the Chou kingdom. The war made the social structure of Chinese society at that time more socially and culturally open. The dominance of the peasant class in the military is also considered a change in the social order and political order prevailing in China. In addition, the emergence of a group of political adventurers who contested the throne weakened the high nobles with their power. The autonomy of the regional rulers in the feudal system also gradually became irregular and successfully conquered, so the nobles only moved on to the administration (Hartati, 2016).

The controlled people have the chaos of social order and misery because of the various wars that have ensued, resulting in the law of the jungle among them, namely who is strong, he will win. Then gradually, intellectuals who conducted the teaching system appeared so that each society had personal integrity. Intellectuals also include moral values and a central element in their education.

Thus, the concept of Confucius is related to the moral character of the officials who have a position and have authority in carrying out their duties and functions for the benefit of their people. Confucianism can be guided by the actions of a person and institutional groups that run by the prevailing power of a country. Proficiency in running a country alone is not enough when accompanied by ethics in office and upholding values and norms in every action.

Meng Tzu's thoughts on the Chinese book Mencius have an idea of political thought that positively reviews Confucianism. Mencius developed his own understanding of the nature of man. While Mencius idealistic thinking is regarded as extreme right, Hsun Tzu can be categorized as extreme left for realistic thinking. Hsun Tzu thinks that human beings are bad, including wanting to be robust and selfish. Hence, the interpretation of Confucianism refers to the scheme of the highest character on behalf of all bureaucratic interests. The power possessed by the officials will benefit one side and the community that has authority on the Confucian scheme that violates norms and morals and human values (The Kong and Foundation, 2017).

\section{B. Implications of Confucian Phenomena Reviewed from a Cultural Superiority Perspective}

The country most affected by Cultural Superiority other than Africa, namely China, which according to research by Jimmy (2015), after years of political independence in most countries in Africa. China also claims that Africa should depend on the model of economic 
development of imports because developing countries, much of which is desired where this conception is a form of Chinese Confucianism towards African countries. The phenomenon of Cultural Superiority of Confucianism owned by China seems to some international circles, asserting the existence of an imported economic model has brought misery and poverty to most citizens. Because the economic development models of the Chinese country has benefited China with the wisdom of developing countries in terms of the boost to economic growth in Africa, Asia and the Americas. In addition, the process of globalization is a major trend both now and in the future as it covers opportunities and risks in many countries (Chulu, 2015).

The implications of Confucianism as Cultural Superiority, one of which is triggering the war. The war also brought about a change in the social mobility norms of Chinese society. Before the war, a period of development of feudalism, the social structure of the Chou people tended to be closed. It can be said that at the time it was almost impossible to improve social status. As long as they live, children born to peasant parents will only become farmers. It is structurally impossible for him to hold a high position in government, even if he has sufficient capabilities. Conversely, children born in aristocratic classes, even if they lack quality, will easily become rulers when they grow up. In such a social structure, hereditary factors (blood) determine a person's fate. With the start of the war, the rules of social mobility changed significantly. The war made the social structure of Chinese society more open than in the past. This change was inseparable from the efforts of the nobility to win the battle. One of their efforts is to increase the number of combat troops. The nobles then tried to recruit people from the peasant class to become combat troops (Rozie, 2017).

The war caused by Confucianism was a tragedy of several countries, based on motives of Confucian interests alone. In contrast, those interests could harm the people and deprive the people of the right to live peacefully. So the location of the benefits of Confucianism itself refers to the aspect of morality developed by the leader as long as he prioritizes societal traditions when determining attitudes and actions in leading the nation. War is a tragedy in human life because it brings so many victims. It is not only the property that is the victim, but also the life. Even the most heartbreaking victim is the death of humankind. It can be analyzed that because of Confucianism in a superior cultural network. Then people easily lose the right of others to find happiness and even the right to live. The death of humankind prompted various caring groups to search for solutions. They teach how people should live a good life and get true happiness. But the positive aspect of Confucianism is that it stimulates the existence of a school whose famous teaching is Confucianism that teaches about the independence of the younger generation to continue the struggle of its predecessors. The school was built by Confucius and later developed by his students. One of the keywords of Confucianism is moral. A person will be good if they can continue to develop their morals, both through education and tradition. Each individual can independently determine their attitudes and actions (Kuhn, 2009).

The cultural aspect of Cultural Superiority is better known as bureaucracy which is about the chain of approval or command involving many people at the lower level rather than the upper level. Bureaucracy is a system of government-run by government employees because it has adhered to the hierarchy and level of office. Decision-making is very important 
and can have a significant influence on the progress of a nation. But in the bureaucratic power scheme on the use of Confucianism, it refers to a sovereign and ethical order of government and able to put the interests of the people above all else. The ruler must be able to make his power the basis in governing honestly and wisely because the prosperity of the people and the welfare of a country is undoubtedly in the leader's hands in carrying out every act of his leadership.

With the start of the war, the rules of social mobility changed significantly. The war made the social structure of Chinese society more open than in the past. This change was inseparable from the efforts of the nobility to win the battle. One of their efforts is to increase the number of combat troops. This is where the nobles then tried to recruit people from the peasant class to become combat troops. The agricultural recruitment system that started in the MSMG period was overgrowing in Warring Countries. According to Hsu Cho-Yun's research, the use of farmers as war troops in the MSMG period has reached about $25 \%$. The figures show that opportunities for farmers to rise to warrior class status are increasingly open. However, most army members are still drawn from the descendants of the warrior class. The number of combat troops of the peasant class increased significantly in the Warring States period, reaching about 56\% (Purwanta, 2004).

\section{Implications of Cultural Superiority Measures Against China's Geostrategy in Dealing with International Dynamics}

The new phenomena in the management of Cultural Superiority are the geopolitical culture. It resulted in the conquered region gradually giving birth to a more centralized system of government. The old regional division system, fu-Yung, was overhauled, and the local government's autonomy was cut down. Instead, a new system of regional division emerged, which became Chun (province) and Hsin (district/ prefecture). Changes to the centralization of power and being driven by distrust are also caused by the need to win battles. The great autonomy of the regional authorities in the feudal system allows for differences in the war strategy between one region and another within one country. In addition, the feudal system also allows for differences of views between central and local governments regarding the war strategy to be taken. In other words, coordinating defenses in a country is difficult because each side feels it has the authority to make its own decisions independently. The presence of centralized forces means that decision-making is made by the command center so that defense and attack can be planned and managed more efficiently (Wang, 2013).

In response to Confucianism in China, the history of war and society's mobility are inseparable. War brought new norms in the social mobility of Chinese society. Everyone can occupy high positions, especially in military areas where the military later developed into an international force, provided they had sufficient capabilities. Social stratification based on blood has also been shifted by new norms emphasizing respect for individual qualities. The second effect of the war was the rivalry between the peasant class and the noble class to achieve key positions. It can be seen that in terms of quantity, farmers have shifted the dominance of the aristocratic class in the military. With this more significant number, the farming class will have more opportunities to produce qualified figures capable of occupying important positions in the military. Each Chinese intellectual has and develops his thoughts on how life is considered good and right. They set up their school, so it is conceivable that 
in the end in society, there are many born views and teachings. As so many schools flourished, the Chinese called it the "School of Philosophy of a hundred." The Chinese call it the term "One Hundred." The long history of Confucianism in China suggests that every event will bring about changes that may never have been imagined before. Each event will have a positive and negative side that can be used as a lesson (Wang, 2013).

\section{CONCLUSION}

This study concludes that the chronological phenomenon of Confucianism in China is an instrument of the Chinese state to gain its position in expanding the country's boundaries. The cultural structure that is changed into the conception of Cultural Superiority has given the meaning that culture can be a geopolitical system for China to influence people around the boundaries of its territory within the scope of Asia, to reach international scales such as Africa with the mechanism of providing assistance to control other countries to follow China's pattern. Based on the above review, there is no culture superior to other cultural development, so the most important thing is the ability of people from any country to change their culture to trigger development to meet their urgent needs in the future. The positive side of the Confucian aspect refers to the fighting spirit. The negative side is triggering the upheaval of war due to differences. However, the concept of Confucianism as a geopolitical instrument indicates that it does not mean that developing countries do not contribute to the development of superpowers such as China. China's growth as a country with a dense demographic and its mention as an industrialized country, culture alone cannot be used as a tool if substantial military capabilities and resilience do not accompany it.

\section{REFERENCES}

Brzezinski, Z. (1997). The Grand Chessboard: American Primacy And Its Geostrategic Imperatives. New York, NY: Basicbooks.

Clydesdale, Greg. (2020). Assimilation, cultural superiority and poverty. Book : Reducing Intergenerational Ethnic Poverty https://doi.org/10.4324/9781003105770-2.

Hartati, Goddess. (2016). Confucianism in Modern Chinese Culture. Paradigm, Journal of Cultural Studies. 2. 174. https://doi.org/10.17510/paradigm.v2i2.25.

Jimmy Chulu. (2015). Africa Is Largely Influenced By Foreign Culture Especially Western Culture. Has Africa Now Sacrificed Her Own Culture On The Altar Of Expediency?. SSRN. Working Paper No.5 of 2015.

Kristensen, N. N. (2019). Cultural journalism-Journalism about culture. Sociology Compass, University of Copenhagen. https://doi.org/10.1111/soc4.12701

Kuhn, D. (2009). The Age of Confucian Rule: The Song Transformation of China. Cambridge, Massachusetts; London, England: Harvard University Press. https://papers.ssrn.com/sol3/papers.cfm?abstract id $=2671784$

Lasiyo, Lasiyo. (2018). The Effect Of Buddhism On Neo-Confucianism In China. Journal Of Philosophy. 28. 92. 10.22146 / Jf.32215.

Lebedeva, Nina. (2020). International Relations in the Great Indian Ocean through the Prism of Geopolitics and Geostrategy. Vestnik RUDN. International Relations. 20. 318-332. https://doi.org/10.22363/2313-0660-2020-20-2-318-332. 
National Geographic. (2018). Confucianism. [Online] https://www.nationalgeographic.org/encyclopedia/Confucianism/ [accessed on 30 May 2021]

Purwanta, H. (2004). Chinese Philosophy Article Series: Confucianism. SPPS, 18 (2), 81-94.

Rozie, Fachroer. (2017). Negeri Sejahtera Ala Konfusianisme Melalui Self Cultivation. Journal KALAM. 6. 177. https://doi.org/10.24042/klm.v6i1.400.

SIDA. (1997). Development Co-Operation In The 21st Century: Project 2015. Stockholm: Swedish International Development Cooperation Agency.

Surbakti, Krista. (2019). Geopolitics and Geostrategy. https://doi.org/10.31227/osf.io/8g9sf. The Kong And Foundation. (2017, April 25). Importance of Mencius in Chinese history [Online] https://thekongdanfoundation.com/the-importance-of-mencius-tochinese-history-and-philosophy/ [accessed on 30 May 2021]

Wang, Y. (2013). Explaining the Tribute System: Power, Confucianism, and War in Medieval East Asia. Journal of East Asian Studies, 13(2), 207-232. https://doi.org/10.1017/S159824080000391X

Weiming, T. (2019, August 12). Confucianism. Encyclopedia Britannica. https://www.britannica.com/topic/Confucianism [accessed on 30 May 2021] 